\title{
Challenges and Opportunities of Landslide Induced Resettlement
}

\author{
Vasanthakumary Selvanayagam ${ }^{1}$, Rekha Nianthi K.W.G ${ }^{2}$ \\ ${ }^{1}$ Department of Geography, Eastern University, Sri Lanka \\ ${ }^{2}$ Department of Geography, University of Peradeniya, Sri Lanka
}

\begin{abstract}
In the recent past landslide and subsidence events occurred in Rattota DS Division have caused severe damages to houses and other properties in Rattota DS Division in Matale District. The communities living in landslide prone areas in this division face much more risk of different types of landslide hazard. Accordingly, the government of Sri Lanka has initiated relocation programs at several locations of this division to ensure the safety life of the affected and people at risk. This study analyses the challenges and opportunities of resettlement programs takes place as post disaster and preventive resettlement. This study employs a multiple approach for data collection, comprising questionnaire survey, interviews, and observation. The results of this study emphasize that resettlement program has brought both negative and positive consequences and it shows inter and intra variation among the estate and rural communities. Problems associated with the selection of the site, selection of the beneficiaries, lack of basic facilities at resettlement sites, and unnecessary delays are identified as the major problems. Moreover, the collective resettlement program worsens the community integration because people from different places have also posted a challenge to adopt the new environment. In turn, some of the positive impacts were also identified from the resettlement program to certain communities, particularly, to estates by providing the housing facilities. Therefore, this study concludes that though resettlement shows diverse phenomenon both in the post and preventive stage, it should be advanced with essential facilities to safeguard the people from landslide hazards in one side to improve the overall development of the communities on another side.
\end{abstract}

Keywords: Landslide, Resettlement, Displacement, Challenges, Opportunities

\section{Introduction}

Worldwide, there are a number of people have been displaced and relocated each year due to various types of natural disasters. Over the last decade, Asian countries have recorded the largest number of victims of natural disasters (Guha Sapir et al., 2012; EM-DAT, 2014). The growing threat of disaster causes a large number of people homeless. In this aspect resettlement, for example, is a common policy employed for post-disaster development and planning in urban and rural areas of developed and developing countries (Tamakloe, 1994; Hall, 1994)

Sri Lanka, being a developing nation, frequently meets severe challenges regarding the displacement induced by natural and man-made disasters. It has witnessed several natural disasters like drought, floods and landslides, etc., increased in the recent past (Sripala, 2009). Among these, landslide brings severe challenges to the government and communities in several aspects. On one side landslides bring severe socio-economic catastrophic to the country through destruction and displacement, on the other side, it lays the demand for relocation and resettlement process. This situation has led serious concern on the communities who are living in the landslide prone areas with various levels of risk. Among the various options of landslide risk management procedure, avoidance of risk is considered as one of the best approaches. Risk management actions are targeted primarily at hazard control, for example, landslide stabilization through engineering works and watershed reclamation plans; where this is not feasible, the aim is to reduce exposure by relocating the exposed population and infrastructure (Fernando, 2011). Accordingly, in any place, if landslide hazard cannot be reduced, people have to move to safer locations to ensure the safe life. It is considered as the appropriate and important strategies in landslide risk reduction phase.

By accepting the truth, the government of Sri Lanka has paid much more concern on relocation and initiated a number of resettlement programs at several locations in landslide-prone areas like; Badulla, Kegalle, Kandy, Nuwara-Eliya etc. Although, there were many researchers have conducted on this subject, still, the landslide resettlement in Sri Lanka has failed to meet its expectation (Vijekumara, 2015). Matale is one of the Districts which encounter similar problems in the recent years.

\section{Disaster, Displacement and Resettlement}

Both disaster and resettlement are highly interconnected terms. Disaster is one of the major root causes of the relocation of any individuals or community as a whole. In the context of disaster, displacement includes all forced population movement resulting from the immediate threat of actual disaster situation regardless of length (Tamakloe, 1994; Hall, 1994). At the same time relocation is defined as the physical movement of people instigated, supervised and carried out by state authorities (UNHCR, 2014). The relocation processes are currently selected mainly considering geological and Geomorphological factors. Socio-economic and cultural factors must also be considered during the resettlement process and the resettlement guidelines must be improved (Devshani and Rekha, 2016).

According to the IDMC [IDMC: Internal Displacement Monitoring Centre, 2014] and NRC [NRC: Norwegian Refugee Council] (2014) disaster based displacement includes all forced population movements resulting from the 


\section{International Journal of Science and Research (IJSR) \\ ISSN (Online): 2319-7064}

Index Copernicus Value (2015): 78.96 | Impact Factor (2015): 6.391

immediate threat of, or actual, disaster situation regardless of length of time displaced, distance moved from the place of origin and subsequent patterns of movement, including back to the place of origin or resettlement elsewhere. States have the primary responsibility to protect the people and property on their territory from hazards, and thus, it is vital to give high priority to Disaster Risk Reduction (DRR) in national policy, consistent with their capacities and the resources available to them (Hyogo Declaration, World Conference on Disaster Reduction, January, 2005).

Identification of the risk areas, and enable the safe lives for people becomes an important phase in the process of disaster risk reduction. Resettlement is a long process that in most post-disaster scenarios will outlast the presence of humanitarian actors (Thomas, 2015). It is a measure for intervention that seeks to address the exposure that is one of the components of vulnerability, and it results in nullification of the risk condition (Fernando Ramirez, 2011). Physically, it means changing the location exposed elements, in this case, the population, so that there is no time-space coincidence with a specific socio-cultural phenomenon that may develop or intensity in the future, (ibid). Generally, the resettlement process occurs in relevant to landslide disaster in two stages such as pre and postdisaster phases. Preventive resettlement is an important initiative in landslide risk reduction process and it includes the resettlement of people who are living in risk areas of the landslide.

According to Elena Correa, (2011), preventive resettlement of populations located in high-risk areas is a corrective measure in which all or part of a community is relocated because of the high risk of disaster. Such a measure should be seen as a last resort when it is impossible to mitigate risk factors associated that cannot be controlled (ibid). Hence, it is a positive effort not only ensures the life of the people but also save the wealth of the government by avoiding unnecessary losses.

Tsung Hsi Fo, et al, (2013) emphasized that if mass disasters damage the landscape and make the residential areas inhabitant and force the habitats to relocate, housing reconstruction becomes severe challenges for post-disaster reconstruction. The tasks for post-disaster reconstruction thus involves not only housing support for the victims, but also community reconstruction (ibid). Where people are being prevented from returning pending resettlement, people will not only be displaced for longer periods but also face increased protection risks, (Thomas, 2015). Because, relocating a population, its economic activities, and its social networks and relations, as well as its natural physical and built environment, are a complex process with significant impacts direct and indirect on the populations and on governments, (Fernando Ramirez, 2011).

\section{Problem Definition}

Being one of the important and catastrophic disasters in Sri Lanka landslide disaster has led a call for resettlement process at several locations in the Central Highland of Sri Lanka. Accordingly, the number of landslide and subsidence events occurred in Rattota DS Division in Matale District becomes an important challenge to the communities and relevant institutions in the recent past. It caused loss of life, damages to the properties and more than a thousand people become homeless. The different types and magnitude of the landslide that had occurred in the recent past had called for serious concern toward landslide risk reduction.

With this background within the last five years, the increased severity and frequency of landslides has led to several challenges in relevant to displacement and resettlement process. With the periodic landslide and subsidence events, a number of efforts were taken to relocate the affected and people at-risk. Accordingly, both post and preventive resettlement programs have been initiated. Even though the resettlement process initiated nearly 4 years ago, it was not successful to meet the need of the particular communities. Hence, each resettlement sites shows the different phases of settlement process due to various reasons. As a result, this problem has viewed as a serious concern by relevant institutions and communities. Accordingly, objectives of this study are to assess the existing status of displacement and resettlement process in the study area and to identify the challenges and opportunities of the existing resettlement process. To study the above problems 5 Grama Niladari (GN) divisions from Rattota Divisional Secretariat (DS) Division in Matale District were selected as follows:

1) Punchysylvakande GN Division: Pitakande

2) Horagolla GN Division: Poyangalawatta

3) Madakumbura GN Division

4) Welangahawatta: GN Division Welangahawatta and Kotagahawala Divisions

5) Bodhikotuwa GN Division

All 5 divisions were selected based on the prevailing landslide risk and resettlement challenges. This particular study was conducted during the period from 2015 to 2016.

\section{Methodology}

This particular study thus focuses on providing empirical evidence of challenges and opportunities of the resettlement process. The first part of this paper discusses the background of displacement and resettlement in the study area while the second part elaborates the challenges and opportunities associated with the resettlement process using the results of the survey. Survey design (cross-sectional design) is the main design in this study and it was adopted by the officials of the government and non-governmental organizations and local communities. Since the study focuses principally on providing an evaluation of resettlement process based on the experience and the survey, both quantitative and qualitative research approaches were chosen. Though this study primarily depends on qualitative data, it is also relying on quantitative data where necessary. The study gathered data based on the following categories.

1) Households living in high-risk areas

2) Affected households, but yet to be resettled

Both primary and secondary data collection methods were adopted to gather the necessary data. Primary data were collected through case studies, key informant interviews, questionnaire survey and direct observation of existing

\section{Volume 6 Issue 7, July 2017 www.ijsr.net}




\section{International Journal of Science and Research (IJSR) \\ ISSN (Online): 2319-7064}

Index Copernicus Value (2015): 78.96 | Impact Factor (2015): 6.391

status and the resettlement site, etc; a questionnaire survey was conducted with the sample of 146 households using stratified random sampling method. Collected data were analyzed primarily based on qualitative techniques. The ranking, scoring and descriptive methods were used as qualitative analysis methods. When analyzing the questionnaires, responses were sorted and coded using an Office package of Microsoft Excel.

\section{Results and Discussion}

\subsection{Landslide and status of displacement}

The study reveals that, compared to the past, there are more people exposed to risk from different types of landslide hazard in the study area such as earth slips, rockslide, and debris flow, etc. Among them, landslide and subsidence disasters are a major source of a growing threat. Over the years, many people have lost their houses, relatives, properties, livelihoods and etc. This situation led many people to displace temporarily or permanently.

More than 1000 people displaced in 2012 alone and they were temporally accommodated in more than 10 camps. Hence, the trend of being displaced due to landslide disaster has been increasing. Therefore, relocation of the people becomes more imperative; accordingly, a number of families have selected for relocation because it was considered as the best option [Resettlement or relocation of the vulnerable communities may be the possible solutions to overcome the situation (Bandara, et al, 2009)] in certain areas.

\subsection{Why resettlement is unavoidable in the study area}

It has been notified in most of the cases of past landslides; natural factors such as intensity of rainfall and geological factors are dominant. Due to the fact, it requires vast number of efforts with financial and technical assistance in terms of hazard prevention and mitigation in the study area. Moreover, mitigation of landslide is even more difficult and impossible in the particular areas where the control of geological factors is dominant like in Madakumbura and Pitakande areas. Apart from this, affected people due to past landslides also cannot be settled again in the same area where the possibilities of second landslides. The combination of these factors has led a path to avoid the risk areas and therefore resettlement of the affected and the people at-risk have become compulsory in the study area. Resettlement has been a major policy in post - disaster reconstruction in the developing countries (Vijekumara, 2015).

\subsection{Resettlement process in the study area}

Resettlement process in the study area initially started in 2011 following the subsidence events occurred in Bodhikotuwa and its vicinity. Subsequently, the need of resettlement process was identified in several other areas as well. Diverse patterns were identified in both post and predisaster resettlement process.

\subsubsection{Post-disaster resettlement}

Post-disaster resettlement process takes place for the affected people by a landslide and subsidence disaster. The major source of the disaster which induces the need of resettlement is shown in the table (01). The Nickloya landslide alone completely destroyed a line rooms and several other houses located along the landslide path.

Table 1: Post-Landslide Disaster Resettlement

\begin{tabular}{|c|c|}
\hline GN Division & Nature of the disaster \\
\hline Nickloya & Debris: Washout in 2012 \\
\hline Welangahawatta & Slump: in 2012 \\
\hline Galgewatta & Cutting failures \\
\hline Bodhikotuwa & Subsidence: 2011 and 2012 \\
\hline
\end{tabular}

\subsubsection{Preventive resettlement}

Apart from the post-disaster resettlement, preventive resettlement also takes place in certain areas to ensure the safety of people at risk. Subsequent to the identification of landslide risk, the households have been selected based on the landslide risk level. In particular, a contemporary status of slope stability is primarily considered in this process. In terms of landslides signs like tensional cracks, small-scale failures, and the cracks developed in the houses, etc. were mostly observed in Madakumbura, Kotagahawela, Poyangalawatta, Dikkumbura, Pitakande Gama, and Welangahawatta areas. Due to this status, people are at risk and therefore preventive resettlement process also becomes imperative. Table 02 summaries the associated risk type and the divisions (village/estate) where preventive resettlement takes place.

Table 2: Preventive resettlement in the study area

\begin{tabular}{|c|c|}
\hline Village/Estate & Identified Risk \\
\hline Kotagahawela & Rock fall \\
\hline Poyangalawatta & Landslide and rock slide \\
\hline $\begin{array}{c}\text { Bambaragala and } \\
\text { Madakumbura }\end{array}$ & Landslide and rock fall \\
\hline Welangahawatta & Landslide and rock fall \\
\hline Dikkumbura & Subsidence and cutting failures \\
\hline
\end{tabular}

Source: Survey data and records of NBRO District office.

\subsubsection{Pattern of resettlement}

The resettlement in the study area shows a diverse pattern based on the selection of beneficiaries, phases of resettlement etc. Three types of resettlement can be found in the study area as follows:

1) Resettlement of entire community

2) Resettlement of sub system

3) Resettlement of individual family

Resettlement takes place in the study area, mostly as a subsystem of the community. Out of five divisions, beneficiaries have been selected as the sub - system in four divisions. At Poyangala Division, the entire community is going to be resettled. In addition, there is a resettlement of single-family also found in Galgewatta division because family from Galgewatta division also has been selected for resettlement since that family had lost two children and house due to the cutting failures occurred in 2012. The resettlement sites and the division names are shown in figure (01).

\section{Volume 6 Issue 7, July 2017 www.ijsr.net}




\section{International Journal of Science and Research (IJSR) \\ ISSN (Online): 2319-7064}

Index Copernicus Value (2015): 78.96 | Impact Factor (2015): 6.391

Out of four sites, two sites are closest to the existing village or estate. However, the major resettlement site Viharagama has situated away from their existing place. Likewise, resettlement process shows a diverse pattern. However, based on the results of the study both resettlement processes have resulted in significant negative and positive impacts. The study reveals that challenges are looming large in this area.

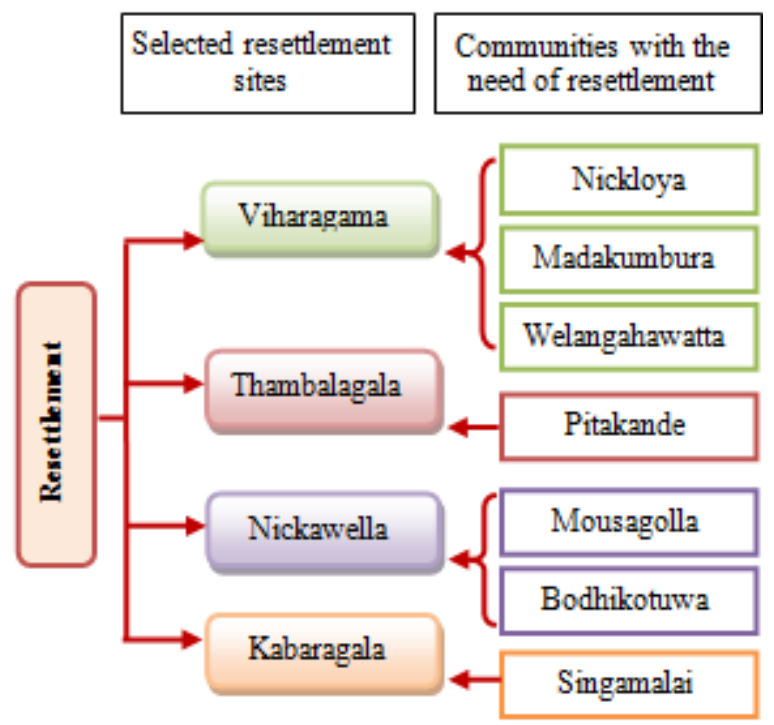

Figure 1: Resettlement pattern in the study area Source: Based on the survey data, 2016

\subsection{Challenges of resettlement in the study area}

Even though, it is an acceptable practice to reduce the landslide risk, it has caused a number of negative impacts and disturbances to the society and the institutions. Some of the important problems were identified in the following areas.

1) Problems regarding the relief of land and houses

2) Selection of the resettlement site

3) Selection of beneficiaries

4) Livelihood and other socio-economic problems

5) Lack of basic facilities

6) Unnecessary delay and un-willingness

\section{i. Problems regarding the land relief and houses}

The primary concern of the government is to provide the land or housing to the affected community. However, the study reveals that modest concern has paid to the overall relief in the study area.

The size of the land, site selection and the selection of beneficiaries were importantly identified. Out of five GN divisions studied, 7 perch land with house relief were provided only for one division. Land relief alone provided to the affected other communities in Singamalai, Welangahawatta, Bodhikotuwa and Madakumbura divisions. However, neither land nor houses have been provided to the SVK [Name of a Division] division and some of the households in Pitakande GN divisions. [All persons, groups and communities have the right to suitable resettlement which includes the right to alternate land or housing, which is safe, secure, accessible, affordable and habitable] Hence, study found that, land relief for Sinhala villagers is different from estate structure. However, provided land is very small there were no rooms for expansion for the houses or any other activities to carry out.

\section{a. Rural structure}

The relief of 10 perch land and financial relief (rupees one lacks) have been provided for villagers excluding house relief. Hence, the size of the land also small in size when compared to what they had before. Study reveals almost all the rural villagers possess own land and the land size is 15 perches in average. Hence, they possessed better housing facilities with homesteads. In this circumstance, they cannot enjoy the benefits at the resettlement site as they enjoyed in their origin place.

\section{b. Estate Structure}

Resettlement process can be considered as an opportunity for the estate community; because it has brought a number of positive facts to them. Even though, they were given 7 perch land, they perceives the resettlement process as a great opportunity. Because, one side, it ensures the safe life from landslides, on the other hand it also provides the opportunities to enjoy the individual housing system. In Pitakande estate alone, 20 families had been given land ( 7 perch) with houses. Hence, individual houses are relatively better when compared to estate line rooms. As a result, communities which are suffered with poor housing for about 150 years will enjoy the benefits from the new housing scheme [In addition to reducing risk, resettlement may also present an opportunity to improve the standard of living of vulnerable groups in high-risk areas (Elena Correa, 2011)]. Discussion with the respondents emphasizes that, social status of the estate people also has improved through resettlement. Respondents from Pitakande Estate said that: "Now we are living in new quarters. We face lots of difficulties when we were in line rooms as it is very congested and very poor facilities. Now, we can proudly say that, we are living in an individual house unit" (Field survey, 2016).

\section{ii. Selection of the resettlement site}

The study reveals that, selection of the appropriate and available site was the primary challenge and foremost factor in the resettlement process [The only available alternative lands are either covered by forest of by tea lands (Dadly Disanayake, 1994)]. The study reveals that, 4 sites have been selected for resettlement. Out of four sites (Viharagama, Thambalagala, Nickloya, Kabaragala), the Viharagama is the major site which accommodates 101 families from 3 GN Divisions such as Nickloya, Madakumbura, and Welangahawatta. Hence, Kabaragala, and Thambalagala resettlement sites were selected to the resettlement of people from closest estate such as Singamalai and Pitakande respectively. Apart from this, 13 families from Bodhikotuwa and Mousagolla area are going to be resettled in Nickawella resettlement site.

It is very essential in resettlement affected people and the people endangered with the threat of landslides should be relocated in safe areas. Therefore, it is very important to ensure the Geotechnical stability of the land. Being a mountainous region Rattota area consists of very limited

\section{Volume 6 Issue 7, July 2017 www.ijsr.net}




\section{International Journal of Science and Research (IJSR) \\ ISSN (Online): 2319-7064}

Index Copernicus Value (2015): 78.96 | Impact Factor (2015): 6.391

residential areas. Those areas also already occupied by the community for several purposes.

The area which is considered as slope gradient over $60 \%$ in Rattota is 587,743 ha in extent. In addition, forest, water bodies, outcrop/bedrock exposures consist of $20.4 \%$ of the total area and about $79 \%$ lands utilized for homesteads, plantation crops, paddy cultivation, etc. Land use in Rattota area (Graph 01) shows how it does difficult to find the resettlement site for more than 100 families in a site with essential facilities.

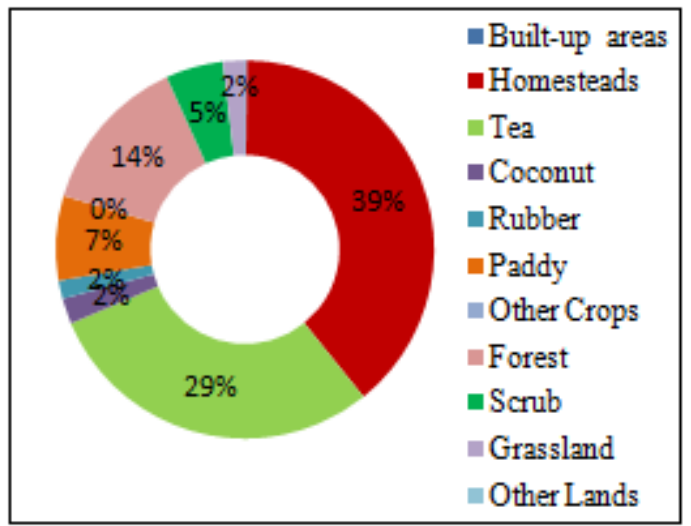

Graph 1: Land use in Rattota DS Division

Source: Reports of Rattota Divisional Secretariat Division, 2015

Therefore, officials face difficulties to find a suitable site with limited options and the shortage of suitable land [The Government of Sri Lanka preference has been to site resettlement schemes on public land. Although the government owns more than 80 percent of Sri Lanka's land, most of it is unavailable for being occupied by national parks \& water catchment areas or given over to long-term agricultural leases (Dissanayake, 1994)]. During the interview with the Land use Policy Planning Officer of Rattota, he has stated that; "Selection of resettlement site is a major challenge in Rattota due to its physical structure. However, considering the need, and socio-economic factors, Viharagama site has been selected as a major resettlement site with some of the minor sites".

Therefore, the selection of the resettlement site has been caused much controversial situation among communities. Both like and dislikes were expressed by respondents regarding the site. In particular, it was found that no any prior discussion regarding the site or housing construction was held with the relevant community [That affected persons, groups and communities provide their full and informed consent as regards the relocation site (UN, 1997)]. The study found that house designing and construction in Pitakande area also held without the concern the particular community.Respondents from Pitakande and Singamalai community said that provided site is, even though concern regarding the site is was not obtained, better than the existing one. In turn, disagreements were expressed by the respondents towards the Viharagama site where more than 100 families going to be resettled [The entire resettlement process should be carried out in full consultation and participation with the affected persons, groups and communities (UN, 1997)]. "We have given land very far from here. However, we were helpless if we say no like. Therefore, for serve our life from landslide threat we have to move even though we were dislike" (Respondents from Welangahawatta).

\section{iii Selection of beneficiaries}

The study reveals that there were disagreements, regarding the selection of the beneficiaries for resettlement has been also identified. According to the officials' the selection of beneficiaries was held based on the landslide risk. However, expectation of community creates different misconception regarding the selection procedure. Even though negative response from the non-beneficiaries is common when communities were selected as a subsystem, there were some situations could not manage by the officials. In particular, both Madakumbura and Pitakande areas conflict among the communities and officials were witnessed during the field survey. In overall, important shortcomings in the selection of beneficiaries were identified as follows:

1) Lack of transparent when selecting the beneficiaries

2) Unavoidable community expectation for land and house

3) Loss of confidence on institution and officials

4) Lack of coordination between officials

It was found that the distribution of houses has caused much controversial situation among the communities. There were circumstances where risk identified, relief not provided to all the affected people. For an example, In SVK Division people have been asked to move due to the risk of tensional crack appeared along the road close to the line-house settlements. Since several houses were developed cracks subsequent to this tensional crack, people living in this area are with the fear of landslides. Though this problem was recognized by the relevant institutions, necessary actions were not being taken [Resettlement process should be prioritized all the affected people. It must ensure equal rights to women, children and indigenous population, (UN, 1997)].

There were instances of allocation of the houses identified in Pitakande, Madakumbura areas to the households who are ineligible or the people with little impact or risk. During the field survey most complaints came from the respondents which show disagreement with the selection of the beneficiaries for resettlement. Reports of NBRO regarding landslide in Pitakande area emphasize that particular line rooms should be relocated to a safer place. However, out of 20 beneficiaries 3 have been selected from little impact areas as well. Respondents from Pitakande estate, Welangahawatta and Madakumabura repeatedly express their disagreement regarding the selection of the beneficiaries.

In turn, a house which is endangered with slope failures was neglected and still at risk. Voiceless people like elders are more unfortunate in this regard. A helpless grandma from Pitakande estate emphasizes that: "We (I and husband) are alone and helpless but living under threat of landslide. You can see where I'm standing on the surface which is moving day by day. My neighbors got land and house, I got nothing. Many have come to see this situation and taking photographs, but no use, our problem will last till we die" (S. Letchumi, Age 69, Retired Estate Worker). 


\section{International Journal of Science and Research (IJSR) \\ ISSN (Online): 2319-7064}

Index Copernicus Value (2015): 78.96 | Impact Factor (2015): 6.391

It was clearly emphases that people are talking a lot about new houses and discrimination in the provision of housing facilities rather than a landslide. They show unwillingness to provide the data to officers even for other necessary purpose due to abhorrence of powerless. The officers who visit this area for any other purposes also face the same problem. People think that, they are collecting data are aimed to provide the housing facilities.

\section{iv. Livelihood and other socio economic problems}

The study reveals that being agricultural based communities they have to face much negative impact with respect to livelihood and other socio-economic status. This was the major source of problems in long term perspectives in the study area. As noted by Vijekumara (2015) $90 \%$ of the newly constructed houses have been abandoned in Galahawatta Resettlement Project due to poor accessibility to existing public and social infrastructure and livelihood opportunities. Therefore, resettlement cannot be successful without ensuring the livelihood and other facilities of the community.

Communities living in this area are economically impoverished and marginalized estate and rural people. They predominantly depend on the agriculture based economy. The livelihood largely depends on paddy, mixed crops, homesteads etc in the rural village. In turn, from the historical period landlessness is a major problem among the estate community. They are economically, socially, politically vulnerable and have suffered due to the multidimensional poverty, poor education, health and housing facilities.

Therefore, communities, which have been already suffered from severe socio-economic deprivation, view the landslide hazard and housing construction as an additional burden. Therefore, when resettle communities it is the primary need of the relevant institutions, to examine the economic \& social-cultural, political needs of them. It should be ensured the capacity of the people to construct the houses. However, the study found that, poor economic condition is one of the important reasons for delaying house construction.

Moreover, their life expenditure also relatively low in existing locations because they accomplish most of their needs by their existing livelihood pattern. In new site, they have to find a new livelihood opportunity because they have not given a land for agriculture purposes. A resident from Welangahawatta area stated that: "I love my village; we have a beautiful paddy land here. Hence we have plenty of water, and land, beautiful environment, the new site worsens our life by restraining all these good things" (Field survey, 2016).

Since they are unfamiliar with other jobs, it is an additional burden to find a livelihood mode as well. However, problems are negligible if the site is close to the former location (Pitakande Estate) and similar livelihoods structure. Study reveals all divisions except Thambalagala face challenges to find a suitable livelihood source [The State shall provide all necessary amenities and services and economic opportunities (UN, 1997)]. Since the resettlement sites are with limited economic opportunities the sudden changes of the place and livelihood opportunities would bring challenges to find new economic opportunities. If the institution fails to provide the better livelihood opportunities to the families they have to face severe socio-economic problems.

\section{v. Lack of basic facilities}

Access to the basic facilities also found as a most important problem in the study area. Only the land or houses have been provided to the people by the institutions. For nearly 4 years have gone from the date they have been given land at resettlement site, some of them have not taken any initiation to move to the resettlement site. Grama Niladari stated that: "Affected people have provided land, but they were not moved yet due to several reasons".

This statement emphasized that there was no concern regarding the community, whether they have the ability to withstand the essential needs or not. As emphasized in UN Report (1997) the actors proposing and/or carrying out the resettlement shall be required by law to pay for any costs associated therewith, including all resettlement costs. Among them, lack of basic facilities is prime factors which weaken the resettlement process for more than 4 years. Vijekumara (2015) in his study found that most the cases have failed due to problems with the accessibility of the new location.

Due to the unavailability of basic facilities, such as water, electricity, transport, etc. they are reluctant to go to the new site, though communities fight for new lands. Respondents show less interest to construct houses in Viharagama site as it considered as very remote area by the communities. The geographic isolation of the Viharagama site has aggravated the problems regarding the transport and other socioeconomic needs as well. This situation was observed mainly in rural villages. They prefer to reside in their existing houses when compared to the inadequate facilities at the resettlement site. This situation leads to more and more vulnerable situation to the next landslide as well.

\section{a. Unavailability of water facilities}

Water, being a crucial need of human life, is inadequate or unavailability in the resettlement site. Respondents narrated water problem as the major reason for delaying housing construction at the resettlement site in Singamalai and Viharagama. This situation creates hardship to the people to be resettled. A respondent from Singamalai emphasis that: "Nearly, 4 years have been passed now; we were not provided water facilities, our humble request is pleasing, provide at least water facilities for us and then we would be able to build at least a cottage and leave this risk area".

Respondents from Welangahawatte stated "We have provided the land four years ago. But we have not moved yet. The main reason is no water facilities at the site". At the Thambalagala site water facilities are relatively better. However, resettled community faces difficulties to get water during the dry season from the main water source is seepages originates from the mountain. Likewise, the study identifies among the reasons for the delay, water facilities is the main reason mostly narrated by the respondents.

\section{Volume 6 Issue 7, July 2017 www.ijsr.net}




\section{International Journal of Science and Research (IJSR) \\ ISSN (Online): 2319-7064}

Index Copernicus Value (2015): 78.96 | Impact Factor (2015): 6.391

\section{b. Lack of infrastructure facilities}

The study revealed that lack of infrastructure was identified as one of the factors which set back the movement of community in the resettlement process [Resettlement after a disaster should be taken place where there is better accessibility to infrastructure, free from disaster and access to community services and social network (Vijekumara, 2015)]. Resettlement processes have been taking place in the study area with the absence of infrastructure facilities. Respondents emphasize that the location of resettlement site will limit their access to schools, health services, job, etc. as it's in a very remote location. This situation isolates the community from other communities. It is one of the important constraints to access other essential services as well [The relevant institutions should think just relocating the people in very remote areas without any essential facilities, (UN report, 1997)]. In turn access to basic facilities is relatively better at the Thambalagala site than their origin of the place. Therefore, people have been settled because relatively better facilities available at the site.

\section{vi. Unwillingness and unnecessary delay}

Resettlement process in the study area is subjected to long delays (nearly 4 years) due to various reasons. According to the interview with the DMC [Disaster Management Centre, Matale District] officials, insufficient funding was found as the major reason for the slow process of resettlement in the study area. Hence, lack of political support to speed up the process is also identified as the limitation in the study area, officials said. Another important problem identified is the unwillingness of the community to move to the new site [During the resettlement programme voluntary resettlement procedures as stated by the rules and regulations of Sri Lankan and Asian Development Bank must be implemented order to avoid unnecessary community protests, (Bandara et al, 2009)]. Different perceptions were obtained from the respondents as follows regarding the willingness of resettlement site; Bodhikotuwa (46\%), Madakumbura $(40 \%)$, Singamalai (32\%), Welangahawatta (40\%), Nickloya (28\%) and they were reluctant to move. These figures show that, except Viharagama site other three sites views as relatively better sites by the respondents.

This problem was mainly found in rural areas like Welangahawatta, Madakumbura division because they have been adopted for prolonged periods in their locality. Both in estate and rural areas, intimacy as a community is very high and they share sorrow and happiness with each other. In addition, moving to new site disconnects the bond with their origin village. Therefore, it creates a number of psychological problems to the community to settle in resettlement site, since site is entirely differing from the areas which they were so far. This phenomenon was widely noted among older people, where they attached to their home environment from birth.

Gemma Sou, (2015), found from the study in Cochabamba, 'Place attachment' - which relates to an individual's sense of identity and belonging heavily discourages people from relocating. This is very true in the study area as well. It is the same in the Meeriyabedda landslide situation; 2014 in Sri Lanka. No matter how much the authorities try to warn them and try to relocate them they tend to live in that own place. It is mainly due to their socio-cultural and economical attachment with the place (Devshani and Rekha, 2016). They experienced with their own society, relations, and friends and with the adopted environment cannot be let pass within a short period of time. Since, this entire system is going to be changed at new site; it creates unwillingness among the communities.

The main reason behind this situation was a limited option to resettlement site and the same time no prior discussions were held with the respective communities. Collective resettlement in Viharagama site faced difficulties due to lack of concern regarding the mix characterized communities from both estate Tamils and Rural Sinhalese. Land-use Policy Planning Officer, Rattota, Wijethunga stated that: "Since the communities are from different ethnicity (Tamil and Sinhala), problems associated with the medium of the schools, religious places and also some other important concerns have to be looked in depth". Likewise, due to the intimacy with the former location people shows unwillingness to move to the new site.

It also narrated by the respondents as one the reason for unwillingness to move. "We built this house under the very difficult situation, how could I leave this house? Over 60 years of memories are with us in this house. Our parents and we grew up here. We don't want to leave because of the memories" (Resident from Bodhikotuwa). "I love my house, because since being a little boy. Because I grew up here, I don't want to move". Because I have good and unforgettable memories of this house" (Resident from Madakumbura).

In addition to these challenges, lack of concern on living with landslide also becomes as major problems in the study area. The resettlement process in the study area has led to less concern on living with a landslide [Obvious path points to contain of the people within the District itself with better preparation of the people to the landslide prone environment. It is better to build a culture of living in landslide prone areas whilst reducing economically oriented pressure on these lands (Dadly Disanayake, 1994)]. The people with less risk also attempt to move to the new place by looking at the people with high risk area due to the loneliness. Without realizing the reality behind the resettlement they are fighting for lands. It was very clearly identified from the discussion with the respondents and the officials in all most all the division. It was a serious concern in the areas where resettlement occurs as subsystem of the particular community like Madakumabura and Welangahawatta.

\subsection{Resettlement as an opportunity}

Apart from the negative impacts some of the positive impacts also experience by the communities living in this area. Resettlement process has ensured the land ownership and housing rights. Unlike in other areas, these 20 families have been resettled in adjoining area called Thambalagala which is very similar to their former estate. The new resettlement site has brought benefits to the community without changing their livelihood pattern. Likewise, people in Singamalai estate also views that the proposed resettlement as a great opportunity. However, they have 


\section{International Journal of Science and Research (IJSR) \\ ISSN (Online): 2319-7064}

Index Copernicus Value (2015): 78.96 | Impact Factor (2015): 6.391

given only land at Kabaragala estate. Since entire estate people going to be resettled, there are no problems emerged from the community. Therefore, encountered problems are very minimal when compared to other communities.

\section{Conclusion}

The results of this study emphasize the displacement and resettlement in this area has brought a number of challenges to the communities and relevant institutions. The risk associated with the landslide in the study area repeatedly emphasizes that avoidance of the risk is the best option. The existing resettlement program has brought both negative and positive consequences and it shows inter and intra variation among the estate and rural communities. Some of the positive facts identified particularly in estate structures, in turn it has brought more problems than a landslide in other areas. In overall, resettlement was not successful in the study area due to several problems associated with it. Therefore, this study emphasizes that resettlement process should be ensured the well-being of the people and society rather than making a foundation for social tragedies. This study suggests that the following recommendations to improve the existing resettlement program and to avoid the problems relevant to resettlement.

\section{Recommendations}

1) The resettlement process should be expedited with necessary steps such as providing the housing or financial reliefs.

2) Those who entitle to relief should be given priority without any discrimination and transparency should be maintained.

3) Water facilities should be provided to the Viharagama and Kabaragala site without further delay.

4) Access to basic and other infrastructure facilities should be ensured at all four resettlement site.

5) The areas Singamalai, Welangahawatta, Madakumbura where provided land only should be supported to build the houses.

6) To ensure the livelihood of the people appropriate livelihood opportunities should be provided.

7) Much needed livelihood assistance which is generally tied to location should be considered during the resettlement process.

8) Long term monitoring throughout the resettlement process is needed to ensure the effective implementation of resettlement.

9) People should be guided to manage the preventable hazard in their locality and to live with landslides.

\section{References}

[1] Corea, Elena, Fernando Ramirez and Haris Sanahuja., (2011), Populations at Risk of Disaster: A resettlement guide, Washington DC: The World Bank: GFDRR.

[2] Devshani, Samaranayake and Rekha Nianthi, K.W.G. (2016), gaps and shortcomings of the early warning system and responses: in Meeriyabedda landslide, 2014 in Sri Lanka, Multidisciplinary International Journal, (MIJ) Vol. No. 2, pp. 37-46.
[3] Dissanayake, D. (1994), Socio- economic concerns of people in landslide prone areas in Sri Lanka: Proceeding of the National symposium on landslide in Sri Lanka. Landslide Studies and Services Division, Colombo. 1994. Vol.1. Sri Lanka: NBRO \& Ministry of Housing, Construction \& Urban Development. pp. 211-114.

[4] Judith Shaw and Iftekhar Ahmed, Design and Delivery of Post-disaster Housing Resettlement Programs: Case studies from Sri Lanka and India, Monash Asia Institute and Monash University.

[5] Perera, TGUP, Weerasooriya \& Karunarathane, HMLP, (2012), "An Evaluation of success and failures in Hambantota, Siribopura Resettlement Housing Program: Lessened learned". Sri Lankan Journal of Real Estate, Department of Estate Management and Valuation, University of Sri Jayewardenepura, Issue 06, pp.1-15.

[6] Samarakoon1, S. M. L. D. Dayawansa N. D. K., Gunawardena, E. R. N., (2016), Evaluation of legal framework for resettlement in Sri Lanka based on resettlement procedure in DeduruOya reservoir project, International Research Symposium on Engineering Advancements 2016 (IRSEA 2016) SAITM, Malabe, Sri Lanka.

[7] Sripala, S. (2009) Application of high resolution stereo satellite images for finding vulnerability to flood and landslide. In: Proceedings of the national symposium on creating Disaster free safer environment. NBRO, Colombo. 2009. Sri Lanka: NBRO \& Ministry of Disaster Management. pp. 53-54.

[8] Tsung-Hsi Fu, Wan-I Lin, and Jyh-Cherng Shieh, (2013), The Impact of Post-Disaster Relocation on Community Solidarity: The Case of Post-Disaster Reconstruction after Typhoon Morakot in Taiwan, World Academy of Science, Engineering and Technology, p.78.

[9] United Nations. (1997), Comprehensive Human Rights Guidelines in Development - Based Displacement, Expert Seminar on the Practice of Forced Evictions, Geneva.

[10] Vijekumara, A. (2015), "Study on the Resettlement Planning Process Applied in Post-Landslide Disaster Resettlement Projects in Sri Lanka" Human Settlement Planning and Training Division, National Building Research Organization, Sri Lanka.

\section{Author Profile}

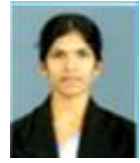

S.Vasanthakumary is Lecturer of Geography, Eastern University, Sri Lanka. She pursued her B.A (hons) degree in Geography from University of Peradeniya with a first class in 2008. Her M.Phil research focused on "Landslide Hazard Risk and Community based resilience". She is the author of many research papers and journal articles, most of which relate to geological hazards, climate change and issues of plantation community in Sri Lanka.

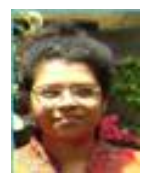

K.W.G. Rekha Nianthi is a senior lecturer at the Department of Geography, University of Peradeniya, Sri Lanka. She obtained her M.Sc from AIT, Bangkok and the $\mathrm{PhD}$ Degree in Geography (Applied Climatology) from NEHU, India in 2005. Postdoctoral research has been completed at the University of Minho, Portugal in 2012/13. Her main research interests are Climatological studies

\section{Volume 6 Issue 7, July 2017 www.ijsr.net}




\section{International Journal of Science and Research (IJSR) \\ ISSN (Online): 2319-7064}

Index Copernicus Value (2015): 78.96 | Impact Factor (2015): 6.391

and Disaster Management and Disaster Risk Reduction. She is a

member of editorial board of the Asian Journal of Environment and

Disaster Management.

Volume 6 Issue 7, July 2017

www.ijsr.net

Licensed Under Creative Commons Attribution CC BY 